\title{
Bencana Covid-19: Stresor bagi Pasangan Suami Istri di Indonesia
}

\section{Covid-19 Disaster: Stressor for Married Couples in Indonesia}

\author{
Sulis Winurini \\ sulis.winurini@dpr.go.id \\ Pusat Penelitian, Badan Keahlian DPR RI \\ JI. Jenderal Gatot Subroto, Senayan, Jakarta, 10270
}

Naskah diterima: 19 September 2020 | Naskah direvisi: 23 Oktober 2020 | Naskah diterbitkan: 31 Desember 2020

\begin{abstract}
The Covid-19 disaster has become a stressor for married couples because it triggers economic, psychological problems, and increases the burden of household domestic work. The purpose of this paper is to get a picture of the stress of married couples in Indonesia facing the Covid-19 pandemic and an overview of their strategies to deal with it. To fulfil this objective, the researcher used the literature review method which was later analyzed using the theory of stress and disasters. The Covid-19 disaster has proven stressful for married couples in Indonesia. However, most of them still try to maintain their marriage. This is in line with Bowlby's theory that people respond to stress by seeking closeness with their loved ones, getting together, and supporting each other through stress, maintaining marital bonds. Home is recognized as the safest way to avoid threats as well as a place to focus on happiness with family.
\end{abstract}

Keywords: Covid-19; disaster; marriage; stress

Abstrak: Bencana Covid-19 menjadi stresor bagi pasangan suami istri karena memicu permasalahan ekonomi, psikis, serta bertambahnya beban pekerjaan domestik. Tujuan dari tulisan ini adalah untuk mendapatkan gambaran stres pasangan suami istri di Indonesia menghadapi pandemi Covid-19 dan gambaran strategi mereka untuk mengatasinya. Untuk memenuhi tujuan ini, peneliti menggunakan metode tinjauan pustaka untuk kemudian ditelaah dengan menggunakan teori stres dan bencana. Bencana Covid-19 terbukti membuat pasangan suami istri di Indonesia menjadi stres. Namun demikian, sebagian besar dari mereka tetap berupaya mempertahankan pernikahan. Hal ini sejalan dengan teori Bowlby bahwa orang-orang merespons stres dengan mencari kedekatan bersama orang-orang yang mereka cintai, berkumpul bersama, dan saling mendukung melalui stres, mempertahankan ikatan pernikahan. Rumah disadari menjadi cara paling aman untuk menghindari ancaman sekaligus menjadi tempat untuk memusatkan kebahagiaan bersama keluarga.

Kata Kunci: bencana; Covid-19; pernikahan; stres 


\section{Pendahuluan}

Sebulan setelah World Health
Organization Coronavirus Disease 2019 (Covid-19) sebagai pandemi, Presiden Joko Widodo menetapkan Covid-19 sebagai bencana nasional melalui Keputusan Presiden Nomor 12 Tahun 2020 tentang Penetapan Bencana Nonalam Penyebaran Coronavirus Disease 2019 (Covid-19) sebagai Bencana Nasional. Hal ini didasari pertimbangan meningkatnya jumlah korban dan meluasnya cakupan wilayah terdampak. Covid-19 terkonfirmasi masuk ke Indonesia di awal bulan Maret 2020, dan hingga kini kasusnya terus melonjak. Pada tanggal 2 Maret 2020, Covid-19 menginfeksi 2 orang di Indonesia, kemudian per 31 Maret 2020 total kasus Covid-19 sudah mencapai 1.528 kasus dan telah tersebar di 32 provinsi (Mukaromah, 2020). Per 8 September 2020, kasus Covid-19 telah menyebar di seluruh Indonesia, terkonfirmasi hingga 200.035 kasus dengan 8.230 kasus meninggal dan 142.958 telah sembuh (Gugus Tugas Percepatan Penanganan Covid-19, 2020).

Pandemi Covid-19 telah membawa situasi yang berbeda dan tidak terprediksi dalam kehidupan keluarga. Selama pembatasan sosial, perubahan rutinitas di dalam keluarga terjadi karena semua aktivitas yang biasa dilakukan di luar rumah dipindahkan ke dalam rumah. Terutama pasangan suami istri harus mampu berbagi peran untuk menyelesaikan tuntutan, baik yang datangnya dari luar maupun dari dalam rumah. Sementara itu, pandemi Covid-19 juga telah menyebabkan terganggunya stabilitas finansial keluarga. Per $27 \mathrm{Mei}$ 2020, Kementerian Ketenagakerjaan (Kemenaker) mencatat jumlah pekerja, mencakup pekerja formal dan informal, pemagang serta calon pekerja migran, yang terkena PHK dan dirumahkan akibat Covid-19 adalah 3,06 juta orang. Akibat pandemi Covid-19, angka pengangguran diperkirakan bertambah 3\% hingga 5\% ("Pekerja Dirumahkan dan Kena PHK," 2020). Permasalahan ekonomi dan psikis serta bertambahnya beban pekerjaan domestik akibat terpusatnya aktivitas di rumah menjadi stresor dalam kehidupan pernikahan suami istri selama pandemi Covid-19.

Beberapa penelitian tentang stres pada pernikahan terkait bencana menyebutkan bahwa stres memengaruhi stabilitas pernikahan. Permasalahan sosial politik dapat memicu krisis ekonomi, kesehatan mental, dan stabilitas keluarga. Misalnya saja, Perang Dunia II dan Perang Vietnam memicu tingginya angka perceraian (LipmanBlumen,1975; South, 1985). Beberapa penelitian lainnya menyebutkan kondisi perekonomian yang buruk melahirkan banyak pengangguran dan hilangnya pendapatan keluarga, diikuti meningkatnya risiko perceraian (South, 1985; Yeung \& Hofferth, 1998). Di sisi lain, ada dua pandangan yang menyatakan bahwa solidaritas pernikahan justru dapat terjadi setelah bencana, yaitu teori kelekatan Bowlby dan teori manajemen teror. Teori kelekatan Bowlby (1988) mengungkapkan bahwa pada tingkat bahaya yang ekstrem, respons orang dewasa dan anak-anak adalah mencari kedekatan untuk memberikan keamanan fisik dan kenyamanan emosional. Hubungan yang terjadi pada pasangan setelah melalui ancaman ekstrem dapat diterjemahkan ke dalam upaya mempertahankan ikatan pernikahan dengan kemungkinan kecil terjadi perceraian (Cohan, Cole, \& Schoen, 2009). Sementara teori manajemen teror menyatakan bahwa pengingat kematian dapat meningkatkan kedekatan hubungan. Kedekatan hubungan yang terjadi melalui perlindungan, kenyamanan emosional, dan sebagai simbol kehidupan yang berkelanjutan, dapat menahan rasa takut untuk merespons pengingat kematian (Mikulincer, Florian, \& Hirschberger, 2003, 2004 dalam Cohan, Cole, \& Schoen, 2009). 
Berdasarkan uraian di atas, pertanyaan yang akan diajukan dalam penelitian ini adalah: Bagaimana gambaran stres pasangan suami istri di Indonesia menghadapi pandemi Covid-19 dan bagaimana strategi mereka untuk mengatasinya? Tujuan dari tulisan ini adalah untuk mendapatkan gambaran stres pasangan suami istri di Indonesia menghadapi pandemi Covid-19 dan gambaran strategi mereka untuk mengatasinya. Untuk memenuhi tujuan ini, peneliti menggunakan metode tinjauan pustaka, yaitu dengan meninjau data-data sekunder dari buku, jurnal, laporan penelitian, dan lainnya terkait permasalahan penelitian untuk kemudian ditelaah dengan menggunakan teori stres dan bencana.

\section{Stres, Bencana, dan Dampaknya terhadap Stabilitas Pernikahan}

Dalam kehidupan sehari-hari, stres digambarkan dengan berbagai emosi seperti frustasi, ketegangan, agresi, atau hanya dengan mengatakan bahwa individu sedang berada dalam tekanan (Grasha \& Kirschenbaum, 1980). Ada tiga pendekatan yang digunakan untuk menjelaskan stres (Sarafino, 1994), yaitu:

1) Stres sebagai suatu stimulus, yaitu pendekatan yang difokuskan pada lingkungan. Lingkungan atau kejadian yang dirasakan sebagai ancaman atau membahayakan sehingga memberikan perasaan tertekan, dapat disebut sebagai stresor.

2) Stres sebagai suatu respons, yaitu pendekatan yang difokuskan pada reaksi seseorang terhadap stresor. Respons tersebut terdiri dari dua komponen yang saling berkaitan, yaitu komponen psikologis dan komponen fisik yang keduanya disebut sebagai strain. Komponen psikologis meliputi perilaku, pola pikir, dan emosi, seperti kita sedang gugup atau khawatir. Komponen fisiknya meliputi respons fisik seperti jantung berdebar.
3) Stres sebagai suatu proses interaksi antara individu dan lingkungannya, yaitu pandangan yang menganggap manusia sebagai agen aktif. Stres bukan hanya stimulus dan respons saja, tapi merupakan suatu proses dan manusia dapat memengaruhi dampak dari stresor dengan strategi tingkah laku, kognitif, dan emosional.

Berdasarkan pendekatan tersebut, Sarafino (1994) mendefinisikan stres sebagai kondisi yang akan timbul bila transaksi antara individu dan lingkungannya mendorong seseorang untuk mempersepsikan adanya ketidaksesuaian antara tuntutan suatu situasi dengan sumber daya yang dimiliki oleh orang tersebut, baik biologis, psikologis, dan sistem sosial. Sementara itu, Atwater (1983) mendefinisikan stres sebagai tuntutan penyesuaian diri yang membutuhkan respons adaptif dari diri kita. Menurutnya, stres bukan hanya sesuatu yang berada di luar diri kita atau reaksi kita terhadapnya, melainkan melibatkan hubungan antara keduanya, yaitu hubungan antara diri kita dengan tuntutan yang kita hadapi. Stres psikologi berkaitan dengan bagaimana kita mempersepsi dan beradaptasi dengan kejadian dan dorongan yang membuat kita tertekan.

Berdasarkan definisi di atas, maka dapat disimpulkan bahwa stres adalah hubungan antara individu dengan lingkungannya, lebih dari sekadar stimulus yang mengancam atau respons terhadap stresor, melainkan proses interaksi antara individu dengan lingkungan yang mengancam. Berkaitan dengan bencana yang dialami pasangan suami dan/atau istri dalam keluarga, maka bencana bisa dikatakan sebagai stresor bagi keluarga tersebut karena menjadi ancaman sehingga memberikan perasaan tertekan pada suami dan/atau istri. Stres di dalam pernikahan akan muncul apabila terjadi ketidaksesuaian antara tuntutan suatu situasi akibat bencana dengan sumber 
daya yang dimiliki suami dan/atau istri sehingga menyebabkan suami dan/ atau istri mengalami kesulitan dalam menyesuaikan diri.

Robinson (1997) menyebutkan ada dua kondisi adaptasi, yaitu bonadaptasi dan maladaptasi. Bonadaptasi adalah adaptasi yang berhasil, artinya keluarga mampu menstabilisasi dan mendapatkan rasa koherensi dan kongruensi saat menghadapi krisis. Maladaptasi adalah adaptasi yang gagal. Anggota keluarga mengorbankan perkembangan dan pertumbuhan pribadi, keberfungsian keluarga mengalami kekacauan, kesejahteraan keluarga, kepercayaan, dan koherensi sangat rendah. Maladaptasi dipandang sebagai situasi krisis. Bagi pasangan suami istri, kondisi bonadaptasi bisa mencakup kestabilan pernikahan atau solidaritas pernikahan, sementara kondisi ketidakstabilan pernikahan yang bisa berujung pada perceraian, termasuk dalam maladaptasi.

Beberapa penelitian tentang stres pada pernikahan terkait bencana menyebutkan bahwa stres memengaruhi stabilitas pernikahan. Permasalahan sosial politik dapat memicu krisis ekonomi, kesehatan mental, dan stabilitas keluarga. Misalnya saja, Perang Dunia II dan Perang Vietnam yang memicu tingginya angka perceraian (Lipman-Blumen, 1975; South, 1985). Beberapa penelitian lainnya menyebutkan kondisi perekonomian yang buruk melahirkan banyak pengangguran dan hilangnya pendapatan keluarga, diikuti meningkatnya risiko perceraian (South, 1985; Yeung \& Hofferth, 1998). Literatur terkait bencana mengemukakan efek ketidakstabilan pernikahan melalui permasalahan kesehatan mental, yang terasosiasi dengan stres pernikahan (Beach \& O'Leary, 1993; Davila \& Bradbury, 1998) dan kemudian perceraian (Karney \& Bradbury, 1995). Hasil penelitian yang dilakukan Cohan dan Cole (2002) tentang pengaruh Badai Hugo pada tahun 1989 terhadap tingkat perceraian di Carolina
Selatan menyebutkan bahwa ada efek kedekatan geografis terhadap peningkatan perceraian pada tahun 1990, setahun setelah badai terjadi. Singkatnya, stabilitas pernikahan rentan terhadap bencana, peristiwa sosial politik yang besar, dan penurunan ekonomi (Cohan, Cole, \& Schoen, 2009).

Di sisi lain, ada dua sudut pandang berbeda yang mengatakan bahwa solidaritas pernikahan justru dapat terjadi setelah bencana. Pertama, teori kelekatan Bowlby. Menurut Bowlby (1988), dalam merespons ancaman, bayi mengembangkan strategi perilaku yang bersifat universal berupa menjaga kedekatan dengan pengasuh untuk mendapatkan keamanan, keselamatan, dan kelangsungan hidup, yang mana sistem kelekatan ini aktif sepanjang hidup. Orang dewasa menunjukkan kedekatan dan mencari dukungan dalam merespons stres yang dapat dikonseptualisasikan sebagai perilaku kelekatan (Hazan \& Shaver, 1994). Di bawah ancaman yang ekstrem, Bowlby mengemukakan bahwa bahaya memicu seseorang untuk mencari kedekatan fisik dengan orang lain yang mereka percaya. Ketika menghadapi bencana, pikiran individu beralih ke orang-orang yang mereka cintai. Para ibu berlari melindungi anak-anak mereka, dan para pria mencari keluarga mereka. Mereka berkumpul bersama dan saling mendukung melalui stres (Hill \& Hansen, 1962, dalam Cohan, Cole, \& Schoen, 2009). Singkatnya, teori kelekatan menunjukkan bahwa pada tingkat bahaya yang ekstrem, respons orang dewasa dan anak-anak adalah mencari kedekatan untuk memberikan keamanan fisik dan kenyamanan emosional. Hubungan yang terjadi pada pasangan setelah melalui ancaman ekstrem dapat diterjemahkan ke dalam upaya mempertahankan ikatan pernikahan dengan kemungkinan kecil terjadi perceraian (Cohan, Cole, \& Schoen, 2009). 
Kedua, teori manajemen teror. Teori ini menyatakan bahwa pengingat kematian dapat meningkatkan kedekatan hubungan. Kedekatan hubungan yang terjadi melalui perlindungan, kenyamanan emosional, dan sebagai simbol kehidupan yang berkelanjutan, dapat menahan rasa takut untuk merespons pengingat kematian (Mikulincer, Florian, \& Hirschberger, 2003, 2004 dalam Cohan, Cole, \& Schoen, 2009). Untuk mengurangi rasa cemas akan kematian, individu mungkin termotivasi untuk melindungi hubungannya yang serius dengan ikatan komitmen jangka panjang dengan menghindari konflik interpersonal (Mikulincer et al., 2003). Hasil penelitian menunjukkan bahwa mahasiswa yang teringat akan kematian melaporkan keinginan yang lebih besar untuk membangun keintiman dan membina komitmen yang lebih besar dengan pasangan mereka saat ini (Florian, Mikulincer, \& Herschberger, 2002; Mikulincer \& Florian, 2000), mengkompromikan standar mereka untuk pasangan (Hirschberger, Florian, \& Mikulincer, 2003), dan duduk dekat dengan orang lain daripada sendirian (Wisman \& Koole, 2003 dalam Cohan, Cole, \& Schoen, 2009).

Studi yang dilakukan Nakonezny, Reddick, dan Rodgers (2004, dalam Cohan, Cole, \& Schoen, 2009) tentang tingkat perceraian dan bencana pemboman di Oklahoma pada tahun 1995 menunjukkan bahwa tingkat perceraian menurun di wilayah sekitar Oklahoma dibandingkan wilayah lain yang secara geografis lebih jauh dari Oklahoma. Hasil lain menunjukkan wilayah lain yang termasuk wilayah metropolitan seperti Oklahoma, meskipun secara geografis jauh dari Oklahoma, juga mengalami penurunan tingkat perceraian dibanding wilayah nonmetropolitan. Hal ini mungkin terjadi karena penduduk yang berada di wilayah metropolitan merasa serupa dengan mereka yang berada di Oklahoma sehingga turut merasa rentan, menunjukkan bahwa kedekatan geografis dan kedekatan psikologis memiliki efek terhadap stabilitas pernikahan akibat bencana (Cohan, Cole, \& Schoen, 2009). Sementara itu, studi yang dilakukan Cohan, Cole, dan Schoen (2009) tentang serangan teroris 11 September mengungkapkan terjadinya penurunan perceraian yang signifikan selama satu bulan di New York, begitu pula halnya di Bergen, Philadelphia, dan Los Angeles, sementara tidak ada perubahan pada Chicago. Sejalan dengan studi tentang perceraian pada kasus pemboman di Oklahoma, mereka yang memiliki kedekatan geografis dan psikologis dengan peristiwa 11 September dan yang akan mengajukan perceraian pada September 2001, memutuskan menunda atau tidak bercerai seandainya bencana tidak terjadi.

\section{Situasi Bencana Covid-19 di Indonesia}

Kasus Covid-19 di Indonesia terus meningkat dan menyebar luas di seluruh wilayah Indonesia hingga kemudian per 13 April 2020 ditetapkan sebagai bencana nasional oleh Presiden Joko Widodo dengan menerbitkan Keputusan Presiden Nomor 12 Tahun 2020 tentang Penetapan Bencana Nonalam Penyebaran Coronavirus Disease 2019 (Covid-19) sebagai Bencana Nasional (BNPB, 2020). Untuk mencegah perluasan penyebaran Covid-19, pemerintah menerapkan kebijakan pembatasan sosial. Pada 31 Maret 2020, Presiden Joko Widodo menandatangani Keputusan Presiden Nomor 11 Tahun 2020 tentang Penetapan Kedaruratan Kesehatan Masyarakat terkait Covid-19 dan Peraturan Pemerintah Nomor 21 Tahun 2020 tentang Pembatasan Sosial Berskala Besar (PSBB) dalam Rangka Percepatan Penanganan Covid-19. Pada 4 April 2020, terbit Peraturan Menteri Kesehatan (Permenkes) Nomor 9 Tahun 2020 tentang Pedoman Pembatasan Sosial Berskala Besar (PSBB). Pada saat itu, DKI Jakarta menjadi wilayah pertama yang mengusulkan PSBB 
dan mendapat persetujuan dari Kemenkes, yang kemudian diikuti daerah lain, seperti Kota Bogor, Kabupaten Bogor, Kota Depok, Kota Bekasi, Kabupaten Bekasi, Kota Tangerang, Kota Tangerang Selatan, Kabupaten Tangerang, Kota Pekanbaru (Nugraheny, 2020). Pada pertengahan April 2020, total ada 2 provinsi (DKI Jakarta dan Sumatera Barat) dan 21 kab/kota yang telah menerapkan PSBB (Sekretariat Kabinet Republik Indonesia, 2020).

PP No. 21 Tahun 2020 menjelaskan, PSBB adalah pembatasan kegiatan tertentu penduduk dalam suatu wilayah yang diduga terinfeksi Covid-19, termasuk pembatasan terhadap pergerakan orang dan/atau barang untuk satu provinsi atau kabupaten/kota tertentu untuk mencegah penyebaran Covid-19. Pembatasan tersebut paling sedikit dilakukan dengan meliburkan sekolah dan tempat kerja, pembatasan kegiatan keagamaan, dan/ atau pembatasan kegiatan di tempat atau fasilitas umum. Sementara berdasarkan Peraturan Menteri Kesehatan No. 9 Tahun 2020, pembatasan dalam PSBB tidak hanya meliburkan sekolah dan tempat kerja, pembatasan kegiatan keagamaan, dan/atau pembatasan kegiatan di tempat atau fasilitas umum, tetapi juga pembatasan kegiatan sosial dan budaya, moda transportasi, dan kegiatan lainnya, khusus terkait aspek pertahanan dan keamanan. Beberapa kebijakan, baik yang berasal dari pemerintah pusat maupun daerah, turut menguatkan PSBB. Misalnya saja, kebijakan belajar dari rumah yang diterapkan pada seluruh jenjang pendidikan, mulai dari jenjang prasekolah hingga perguruan tinggi, baik negeri maupun swasta. Selain itu, kebijakan kerja dari rumah, lalu, kebijakan larangan mudik pada Idul Fitri $1441 \mathrm{H}$. Khusus di wilayah zona merah, pemerintah bersama MUI mengimbau agar salat tarawih dan salat id selama masa pandemi Covid-19 dilakukan di rumah masing-masing untuk mencegah kerumunan yang dapat meningkatkan risiko penyebaran Covid-19.
PSBB disadari berdampak langsung pada aktivitas ekonomi dan potensi terjadinya krisis ekonomi. Banyak pakar menilai kemungkinan Indonesia masuk ke jurang resesi pada kuartal III 2020 dengan melihat pertumbuhan ekonomi Indonesia yang menurun drastis hingga minus 5,32\% pada kuartal II 2020 dengan mengacu data dari BPS (Catriana et al., 2020). Per 27 Mei 2020, Kementerian Ketenagakerjaan (Kemenaker) mencatat jumlah pekerja, mencakup pekerja formal dan informal, pemagang serta calon pekerja migran, yang terkena PHK dan dirumahkan akibat Covid-19 adalah 3,06 juta orang. Akibat pandemi Covid-19, angka pengangguran diperkirakan bertambah 3\% hingga 5\%. Sebelumnya, Menteri Perencanaan Pembangunan Nasional (PPN)/Kepala Badan Perencanaan Pembangunan Nasional (Bappenas) memperkirakan jumlah pengangguran bisa mencapai 10,7 juta hingga 12,7 juta orang pada tahun 2021. Proyeksi jumlah pengangguran itu membuat tingkat pengangguran terbuka (TPT) akan mencapai kisaran 7,7\% hingga $9,1 \%$ pada tahun 2021. Asumsi ini berasal dari perkiraan pertambahan jumlah pengangguran sekitar 4 juta hingga 5,5 juta orang pada tahun 2020. Sementara Badan Pusat Statistik (BPS) mencatat jumlah pengangguran sekitar 6,88 juta pada Februari 2020. Jumlah ini setara dengan TPT sebesar 4,99\%. Artinya, jumlah pengangguran pada tahun 2020 kemungkinan akan mencapai 10,88 juta sampai 12,38 juta di tahun 2020 ("Pekerja Dirumahkan dan Kena PHK," 2020).

Dengan kondisi tersebut, pembatasan sosial disadari tidak bisa dilakukan dalam jangka panjang hingga vaksin ditemukan. Awal Mei 2020, Presiden Joko Widodo meminta masyarakat Indonesia untuk bisa berdamai dan hidup berdampingan dengan Covid-19. Istilah "new normal" atau kenormalan baru di tengah pandemi Covid-19 menjadi tidak asing. Kenormalan baru merupakan pola hidup baru, yaitu membiasakan hidup sehat terus-menerus 
hingga bisa tetap produktif dan aman dari Covid-19 di masa pandemi (Kementerian Kesehatan, 2020). Dengan konsep kenormalan baru, masyarakat dan semua institusi dapat menjalankan aktivitasnya, tetapi harus diimbangi dengan kedisiplinan menerapkan protokol kesehatan yang ketat dan tetap melakukan pembatasan fisik. Setiap orang wajib menggunakan masker ketika berada di luar rumah, sering cuci tangan, menghindari kontak fisik dengan orang lain (seperti bersalaman, cium tangan, dan lainnya), menjaga jarak dengan orang lain sekitar 1,5 hingga 2 meter dengan orang lain yang berada di sekitar, menghindari kerumunan, makan makanan bergizi seimbang, istirahat cukup, dan rajin olahraga. Sementara tempat kerja dan industri mengikuti protokol kesehatan yang ditetapkan pemerintah melalui Keputusan Menteri Kesehatan Nomor HK.01.07/Menkes/328/2020 tentang Panduan Pencegahan dan Pengendalian Coronavirus Disease 2019 (Covid-19) di Tempat Kerja Perkantoran dan Industri dalam Mendukung Keberlangsungan Usaha pada Situasi Pandemi, dan Surat Edaran Nomor HK.02.01/ Menkes/335/2020 tentang Protokol Pencegahan Penularan Coronavirus Disease (Covid-19) di Tempat Kerja Sektor Jasa dan Perdagangan (Area Publik) dalam Mendukung Keberlangsungan Usaha.

Namun demikian, realitanya, kenormalan baru tidak berjalan sebagaimana mestinya. Masyarakat Indonesia memiliki karakteristik sosial yang beragam sehingga pemahaman, sikap, berikut tindakannya juga beragam dalam menghadapi pandemi Covid-19. Sebagian masyarakat bahkan menerapkan kenormalan baru seperti situasi normal sebelum pandemi Covid-19. Mereka tetap menjalankan aktivitas tanpa memperhatikan protokol kesehatan. Masih banyak orang yang enggan menggunakan masker di tempat umum, atau kalau pun menggunakan masker, tidak dilakukan dengan tepat. Sementara itu, kerumunan tidak dapat dihindari, terutama area pasar, olahraga, mal, tempat makan, area wisata. Masyarakat mulai berkunjung ke tempat kerabatnya, acara mulai digelar tanpa diimbangi penerapan protokol kesehatan sebagaimana mestinya.

Akibatnya, kasus Covid-19 bertambah parah. Klaster-klaster Covid-19 baru bermunculan, seperti klaster pemukiman padat, klaster pasar, klaster pusat pelayanan kesehatan, klaster perkantoran, klaster rumah ibadah. Kasus Covid-19 melonjak drastis. Per 8 September 2020, kasus Covid-19 terkonfirmasi di Indonesia mencapai 200.035 kasus, dengan penambahan 3.046 kasus. Sebanyak 8.230 meninggal, dan 142.958 telah sembuh (Gugus Tugas Percepatan Penanganan Covid-19, 2020). Jika menghitung ke belakang, untuk kenaikan per 50 ribu kasus, yaitu dari 2 kasus hingga mencapai 50 ribu kasus, awalnya membutuhkan 115 hari (periode 2 Maret-25 Juni 2020). Lalu kenaikan dari 50 ribu kasus hingga 100 ribu kasus membutuhkan 32 hari (periode 26 Juni-27 Juli 2020). Kemudian kenaikan 100 ribu kasus hingga 150 ribu kasus membutuhkan 26 hari (periode 28 Juli-22 Agustus 2020), dari saat ini, kenaikan 150 ribu kasus hingga mencapai 200 ribu kasus membutuhkan 17 hari (periode 23 Agustus-8 September 2020). Artinya, laju kecepatan penyebaran virus semakin lama semakin cepat, padahal jumlah tes per hari stagnan di rata-rata 17.216. Sebanyak $65,56 \%$ kabupaten/kota masuk risiko penularan sedang hingga tinggi. Data Satgas Covid-19 menunjukkan kesenjangan penambahan kasus baru dan kesembuhan melebar sehingga ketersediaan tempat perawatan makin terbatas (Yossihara, 2020: 15).

\section{Karakteristik Bencana Covid-19 sebagai Stresor}

Bencana pandemi Covid-19 memiliki karakteristik tersendiri. Ada dua macam kondisi yang menjadikan bencana Covid-19 sebagai stresor karena memunculkan rasa 
keterancaman bagi individu yang berada di wilayah terdampak. Pertama adalah bahaya dari Covid-19 itu sendiri. Virus SARS-Cov 2 penyebab Covid-19 tidak hanya menyebar melalui droplet dari orang yang terinfeksi, tetapi juga bisa melalui udara, terutama dalam kondisi ramai, tertutup, dan berventilasi buruk. Kondisi seperti ini membuat virus menyebar lebih mudah dan lebih cepat dengan jangkauan yang luas. Selain itu, ada kemungkinan orang yang terinfeksi Covid-19 tetapi belum dan/atau tidak menunjukkan gejala sudah menularkannya kepada orang lain. Belum tersedianya vaksin untuk Covid-19 turut menjadi permasalahan, membuat perasaan terancam dan ketidakpastian masih terus berlanjut. Berita-berita negatif tentang Covid-19, yang sering disertai hoax, bermunculan secara intensif dan masif. Tidak hanya televisi dan media massa yang terus menayangkan kenaikan kasus Covid-19. Media online seperti facebook, grup-grup whatsApp, instagram, penuh dengan berita tentang mereka yang mengalami Covid-19 secara langsung, merasakan kehilangan kerabatnya akibat Covid-19, atau tentang pengalaman negara lain yang collapse menghadapi Covid-19. Gambar atau video mencekam, seperti iringan truk yang membawa jenazah Covid-19, gambar jenazah yang tergeletak di pinggir jalan akibat tidak tertangani pemakamannya, turut menambah tekanan.

Bagi individu dan/atau kerabat dekatnya yang terkena paparan Covid-19 atau bahkan meninggal karena Covid-19, stresor terasa lebih menekan. Sebagaimana yang diungkapkan dalam hasil survei PDSKJI, sebagian masyarakat mengalami atau menyaksikan peristiwa tidak menyenangkan akibat Covid-19 menjadi pemicu stres traumatik (PDSKJI, 2020). Sebagian orang yang terinfeksi memerlukan perawatan khusus di rumah sakit, sedangkan pada situasi saat ini, dengan jumlah kasus yang terus melonjak, ketersediaan rumah sakit dan tenaga kesehatan semakin terbatas. Mereka yang bergejala ringan dan isolasi di rumah sekali pun memerlukan perlakuan khusus dari keluarga yang merawat untuk mencegah penyebaran virus. Begitu pula dengan mereka yang akhirnya meninggal akibat Covid-19. Jenazah Covid-19 dimakamkan dengan prosedur tersendiri tanpa bisa dihadiri keluarga, menjadikan duka yang semakin dalam.

Kedua, stresor berupa pembatasan sosial dan fisik sebagai efek samping dari keberadaan pandemi Covid-19. Rumah menjadi pusat aktivitas bersama keluarga karena orang-orang dituntut memindahkan semua aktivitas yang biasa dilakukan di luar rumah ke dalam rumah. Situasi yang demikian membawa perubahan pada rutinitas di dalam keluarga. Mereka yang bekerja dari rumah dihadapkan pada situasi untuk tetap bisa menyelesaikan tuntutan pekerjaan dengan jam kerja yang cenderung lebih panjang dalam keadaan yang tidak ideal karena terbatasnya fasilitas dan bercampurnya beban domestik. Pasangan dengan anak memiliki tanggung jawab tambahan untuk merawat anak-anak saat bekerja, memastikan bahwa anak-anak menyelesaikan tugas sekolah dan tetap aman dari paparan. Dalam banyak kasus, dukungan dari jaringan sosial pasangan yang lebih luas terbatas, penitipan anak dan sekolah ditutup, memperberat penyesuaian di tengah tekanan pandemi Covid-19. Keadilan dalam pembagian peran suami istri menjadi isu kritis selama pandemi Covid-19 dan upaya menegakkan keadilan ini memerlukan energi tambahan bagi suami istri menghadapi pandemi Covid-19.

Selain membawa perubahan dalam rutinitas, terbatasnya pergerakan serta interaksi sosial dalam kurun waktu yang lama selama pandemi Covid-19 dapat memicu tekanan psikologis. Pernyataan Thakur dan Jain (2020) turut menguatkan hal ini. Mengacu pada kasus di India, Amerika Serikat, Saudi Arabia, dan Inggris, isolasi selama pandemi Covid-19 kemungkinan berkontribusi pada kasus 
bunuh diri. Kasus yang umumnya terjadi akibat pembatasan sosial adalah cabin fever. Istilah cabin fever merujuk pada emosi negatif seperti lekas marah, jenuh, murung, depresi, dan merasa tidak puas sebagai respons terhadap pengurungan, isolasi, cuaca buruk, rutinitas, atau kekurangan stimulasi (Rosenblatt, Anderson, \& Johnson, 2010). Beberapa gejala umum yang dirasakan mereka yang mengalami cabin fever, yaitu demotivasi, merasa putus asa, kosong, dan kehilangan empati, gangguan konsentrasi yang membuat seseorang tidak produktif, insomnia-parasomnia, serta gejala otomotif. Situasi ini akan memburuk apabila keluarga memiliki riwayat konflik, kekerasan, dan permasalahan hubungan dengan anggota keluarga lain, seperti dengan pasangan, anak, orang tua, dan/ atau mertua. Pada kasus di mana keluarga memiliki keterbatasan dalam penggunaan teknologi, adanya pembatasan sosial membuat mereka terputus dengan dunia luar. Keluarga menjadi satu-satunya lingkungan yang ditemui selama 24 jam penuh. Untuk sementara waktu mereka hanya bisa mengandalkan segala sesuatu yang ada di rumah sebagai alternatif untuk tetap memenuhi kebutuhan rekreasi yang biasa mereka dapatkan dari luar rumah.

Implikasi lain dari pembatasan sosial adalah hilangnya atau berkurangnya pendapatan keluarga, misalnya akibat PHK, menurunnya daya beli, atau bahkan penutupan usaha. Survei pertama yang dilakukan oleh Sunarti (2020) terhadap 1.331 responden di seluruh Indonesia pada tanggal 30 April hingga 6 Mei 2020 mengungkapkan sebanyak 52,8\% responden mampu memenuhi kebutuhan keluarga 1-2 bulan ke depan. Hanya $18 \%$ responden yang mampu memenuhi kebutuhan keluarga sampai lebih dari 1 tahun. Survei kedua yang dilakukan terhadap 809 responden pada tanggal 6 hingga 16 Juni 2020 mengungkapkan kondisi yang sedikit lebih baik. Sebanyak $45 \%$ responden mampu memenuhi kebutuhan keluarga sampai 1-2 bulan ke depan dan hanya $25 \%$ responden yang mampu memenuhi kebutuhan keluarga sampai lebih dari 1 tahun. Perbedaan hasil terjadi kemungkinan karena pada bulan Juni 2020, saat survei kedua dilaksanakan, kenormalan baru mulai diterapkan, sementara saat survei pertama dilaksanakan, yaitu pada bulan Mei 2020, pembatasan sosial masih diberlakukan. Hasil survei Sunarti (2020) yang lain mengungkapkan selama pandemi Covid-19 berlangsung, sebanyak $76,6 \%$ keluarga mencari informasi bantuan pangan, sebanyak $79,6 \%$ keluarga mengurangi porsi makan, sebanyak 50,6\% keluarga mengurangi jenis lauk yang dikonsumsi, sebanyak 40,3\% keluarga membeli pangan yang harganya lebih murah, sebanyak 22,5\% menghemat pengeluaran untuk pangan keluarga. Tampak bahwa pandemi Covid-19 membawa dampak yang nyata terhadap kondisi perekonomian keluarga.

\section{Gambaran Stres Pasangan Suami Istri di Indonesia dan Strategi Mengatasinya}

Sebagaimana efek dari bencana pada umumnya, stres menjadi permasalahan lanjutan bencana. Survei yang dilakukan BKKBN terhadap 20.680 responden dari 19 April hingga 3 Mei 2020 menggambarkan bahwa sebagian besar responden (96\%) mengalami emosi negatif akibat bencana pandemi Covid-19. Emosi negatif yang dimaksud adalah gugup atau hati berdebar-debar karena khawatir keluarga terkena Covid-19, mudah menangis atas bencana Covid-19, merasa sedih/kelabu/kesepian atas bencana Covid-19, sulit tidur/istirahat, cemas atas bencana Covid-19, membayangkan halhal buruk terjadi atas bencana Covid-19, merasa putus asa tentang masa depan keluarga karena bencana Covid-19, lepas kontrol/temperamen/marah-marah karena frustasi ketakutan atas bencana Covid-19, berpikir bunuh diri karena putus asa atas 
bencana Covid-19 (Pusat Penelitian dan Pengembangan KB dan KS BKKBN, 2020: 44-45).

Emosi yang paling banyak dirasakan responden adalah perasaan gugup/hati berdebar-debar dikarenakan kekhawatiran keluarga terkena Covid-19 (88\%), merasa sedih/kelabu/kesepian atas bencana Covid-19 (78\%) dan membayangkan halhal buruk terjadi atas bencana Covid-19 (78\%). Sekitar $40 \%$ keluarga sudah ada yang mengalami putus asa tentang masa depan keluarga karena bencana Covid-19. Hampir 1\% keluarga bahkan berpikir bunuh diri karena putus asa selama pandemi Covid-19. Sementara 29\% keluarga sudah mengalami gejala fisik, yaitu jantung berpacu dengan cepat dan keras ketakutan atas Covid-19 dan 16\% responden lepas kontrol/temperamen/marah-marah (Pusat Penelitian dan Pengembangan KB dan KS BKKBN, 2020: 45-46). Sementara survei lain yang dilakukan oleh Sunarti (2020) mengungkapkan bahwa sebanyak 34,6\% responden takut akan kematian diri sendiri, $67,6 \%$ responden takut akan kematian anggota keluarga, $77,7 \%$ cemas keluarga terkena Covid-19, 57,7\% cemas dengan perekonomian keluarga, $48,4 \%$ cemas akan ketidakpastian.

Sebagai upaya mengatasi pengalaman stres, pasangan suami istri di Indonesia melakukan strategi untuk mempertahankan keharmonisan keluarga di masa pandemi Covid-19. Sebanyak 99\% suami dan istri saling mendukung dalam menghadapi kesulitan pandemi Covid-19, 98\% suami dan istri saling mengalah untuk menghindari pertengkaran, $97,7 \%$ suami dan istri menerima kondisi keluarga saat ini apa adanya (Pusat Penelitian dan Pengembangan KB dan KS BKKBN, 2020: 40). Selain itu, suami istri mampu berbagi peran secara seimbang selama masa pandemi Covid-19, bahkan hingga urusan domestik, yaitu saling mengajak dan mengingatkan keluarga untuk berpikir dan berperilaku positif saat menghadapi pandemi Covid-19 (87,9\%), saling mengajak dan mengingatkan keluarga untuk beribadah dan berdoa agar terhindar dari pandemi Covid-19 (86\%), saling mengajak dan mengingatkan keluarga untuk hidup sehat selama pandemi Covid-19 (82,5\%), saling mengasuh anak selama pandemi Covid-19 (71,5\%), saling mengerjakan pekerjaan rumah (49,1\%), saling membeli keperluan sehari-hari $(53,8 \%)$. Secara umum, keluarga Indonesia tetap bahagia selama pandemi Covid-19, yaitu $59 \%$ setuju dan $22 \%$ sangat setuju. Sebanyak 50\% keluarga setuju dan $47 \%$ keluarga sangat setuju untuk tetap bersyukur atas anugerah Tuhan Yang Maha Esa. Selain itu, sebanyak $61 \%$ setuju dan 33\% sangat setuju bahwa komunikasi atau interaksi antaranggota keluarga dalam kondisi baik selama pandemi Covid-19 (Pusat Penelitian dan Pengembangan KB dan KS BKKBN, 2020: 31-33).

Bencana pandemi Covid-19 di Indonesia termasuk bencana yang bisa diprediksi, bukan bencana yang tiba-tiba terjadi tanpa peringatan seperti bencana serangan teroris 11 September atau pemboman Oklahoma. Kalau mengacu pada kasus-kasus yang lain, bencana yang bisa diprediksi, seperti bencana badai Hugo, diikuti angka perceraian yang tinggi. Sebaliknya, bencana yang tidak diprediksi, seperti bencana pemboman Oklahoma dan serangan teroris 11 September, memiliki angka perceraian yang rendah. Pada bencana pandemi Covid-19 di Indonesia, sebagian besar pasangan suami istri justru berupaya mempertahankan pernikahan mereka. Ada karakteristik bencana pandemi Covid-19 yang perlu diperhatikan. Meskipun bisa diprediksi dan disertai upaya pencegahan, bencana pandemi Covid-19 terus membawa ancaman kematian selama vaksin belum ditemukan. Sebagian besar penduduk Indonesia memang tidak terpapar Covid-19, dan kalau pun terpapar, sebagian besar tidak bergejala atau tidak merasakan sakit. Namun ancaman Covid-19 tampak nyata karena laju 
penyebaran yang semakin cepat. Mengacu pada data per 8 September 2020, tingkat kematian Covid-19 di Indonesia sekitar 4\%, lebih tinggi dibanding tingkat kematian global yaitu sekitar $3,2 \%$, lebih tinggi juga dibandingkan dengan rata-rata tingkat kematian penyakit lain, yaitu sekitar $1 \%$. Data kenaikan kasus Covid-19 yang diinformasikan setiap hari, berita yang muncul dari beragam media secara intens dan masif menjadi pengingat kematian yang menguatkan persepsi masyarakat akan risiko Covid-19.

Selain itu, pandemi Covid-19 dirasakan hampir di semua negara. Negara-negara dengan kasus Covid-19 yang tinggi membawa efek kedekatan psikologis bagi Indonesia. Hal ini karena Indonesia sempat diprediksi sebagai negara yang berpotensi menjadi episentrum Covid-19, mengingat jumlah penduduknya yang banyak. Negara-negara dengan kasus Covid-19 yang tinggi terlihat collapse menghadapi Covid-19 sehingga angka kematian semakin ekstrem. PSBB memang menjadi stresor bagi masyarakat. Namun kondisi setelah PSBB tidak diberlakukan bisa menjadi stresor baru. Banyak orang menjadi lebih santai menghadapi kenormalan baru, bahkan terkesan tidak lagi peduli dengan protokol kesehatan. Situasi seperti ini justru mengancam karena mendukung penyebaran Covid-19 yang kemudian akan mendekatkan Indonesia pada kondisi episentrum Covid-19. Tetapi poin yang bisa ditangkap dalam pemaparan di atas bahwa jika dikaitkan dengan teori manajemen teror, maka faktor pengingat kematian tidak dirasakan oleh semua orang di Indonesia. Sebagian orang memiliki persepsi yang kuat mengenai risiko Covid-19, sementara sebagian lainnya tidak, tergambar dari ketidakpatuhan mereka terhadap pelaksanaan protokol kesehatan.

Apabila menggunakan teori kelekatan Bowlby, orang-orang merespons stres akibat bencana pandemi Covid-19 dengan mencari kedekatan dengan orang-orang yang mereka cintai, berkumpul bersama, dan saling mendukung melalui stres, mempertahankan ikatan pernikahan. Meskipun bencana pandemi Covid-19 menyebabkan stres pada pasangan suami istri di Indonesia, namun sebagian besar dari mereka tetap berupaya mempertahankan pernikahan dengan menjaga keharmonisan keluarga di masa pandemi Covid-19, seperti saling mendukung satu sama lain melewati kesulitan, termasuk mengatasi krisis ekonomi bersama-sama, saling mengalah untuk menghindari pertengkaran, menerima kondisi keluarga saat ini apa adanya, saling mengingatkan untuk berpikir dan berperilaku positif, saling menguatkan dari sisi religiusitas, berbagi peran hingga urusan domestik, menjaga komunikasi atau interaksi antaranggota keluarga. Adanya pembatasan sosial menjadi kesempatan bagi suami istri untuk menjadikan keluarga sebagai tempat untuk memusatkan kebahagiaan, termasuk kesempatan untuk mensyukuri anugerah Tuhan karena masih bisa bersama-sama dengan keluarga.

\section{Penutup}

Pandemi Covid-19 terbukti membuat pasangan suami istri di Indonesia menjadi stres. Namun demikian, sebagian besar dari mereka tetap berupaya mempertahankan pernikahan dengan menjaga keharmonisan keluarga di masa pandemi Covid-19, seperti saling mendukung satu sama lain melewati kesulitan, termasuk mengatasi krisis ekonomi bersama-sama, saling mengalah untuk menghindari pertengkaran, menerima kondisi keluarga saat ini apa adanya, saling mengingatkan untuk berpikir dan berperilaku positif, saling menguatkan dari sisi religiusitas, berbagi peran hingga urusan domestik, menjaga komunikasi atau interaksi antaranggota keluarga. 
Bencana Covid-19 terus membawa ancaman kematian selama vaksin belum ditemukan. Data kenaikan kasus Covid-19 yang diinformasikan setiap hari, berita yang muncul dari beragam media secara intens dan masif menjadi pengingat kematian yang menguatkan persepsi masyarakat akan risiko Covid-19. Orangorang merespons stres dengan mencari kedekatan bersama orang-orang yang mereka cintai, berkumpul bersama, dan saling mendukung melalui stres, mempertahankan ikatan pernikahan. Rumah disadari menjadi cara paling aman untuk menghindari ancaman sekaligus menjadi tempat untuk memusatkan kebahagiaan bersama keluarga.

Lebih lanjut, tulisan ini masih memiliki keterbatasan, yaitu hanya mengandalkan data-data sekunder, serta belum menyandingkannya dengan data-data perceraian di Indonesia selama pandemi Covid-19 sehingga belum menggambarkan stabilitas pernikahan. Tampaknya perlu ada penelitian lanjutan terkait kehidupan pernikahan di Indonesia selama pandemi Covid-19 dengan menggunakan konsep, seperti marital quality, marital well-being, marital happiness, marital stability, untuk mendapatkan gambaran kehidupan pernikahan yang lebih komprehensif.

\section{Daftar Pustaka}

Atwater, E. (1983). Psychology of Adjustment: Personal Growth In A Changing World. 2nd.ed. New Jersey: Prentice-Hall, Inc.

Beach, S. R. H., \& O'Leary, K. D. (1993). Dysphoria and marital discord: Are dysphoric individuals at risk for marital adjustment? Journal of Marital and Family Therapy, 19, 355-368.

BNPB. (2020, April, 13). Presiden Tetapkan COVID-19 sebagai Bencana Nasional. Diakses dari https://bnpb.go.id/berita/ presiden-tetapkan-covid19-sebagaibencana-nasional\#: :text=JAKARTA\%20 $\% 2$ D \% 20 Presiden \% 20 J oko \% 20
Widodo\%20 secara, \%2 D 19) \% 20 Sebagai\%20Bencana\%20Nasional.

Bowlby, J. (1988). A secure base: Clinical applications of attachment theory. London: Routledge.

Catriana, E., Ulya, F. N., Idris, M., Fauzia, M., Setiawan, S. R. D., Uly, Y. A. (2020, Agustus, 3). Indonesia Menuju Resesi. kompas.com. Diakses dari https://jeo.kompas.com/indonesiamenuju-resesi-pertama-sejak1998\#utm_source=kompas.com\&utm medium $=$ kgnotif\&utm_campaign=update pertumbuhan-ekonomi-kuartal-ii-2020terendah-sejak-1999-indonesia-menujuresesi\&message_id=22685a32-7fd5-4c01b5cf-1c16e2fb8f1a\&received_count $=1$.

Cohan, C. L. \& Cole, S. (2002). Life course transitions and natural disaster: Marriage, birth, and divorce following Hurricane Hugo. Journal of Family Psychology, 16, 14-25.

Cohan, C. L., Cole, S. W., \& Schoen, Rt. (2009). Divorce Following the September 11 Terrorist Attacks. Journal of Social and Personal Relationship, 26(4), 512-530.

Davila, J. \& Bradbury, T. N. (1998). Psychopathology and the marital dyad. Dalam L. L'Abate (Ed.). Family psychopathology: The relational roots of dysfunctional behavior. New York: Guilford Press.

Florian, V., Mikulincer, M., \& Hirschberger, G. (2002). The anxiety-buffering function of close relationships: Evidence that relationship commitment acts as a terror management mechanism. Journal of Personality and Social Psychology, 82, 527-542.

Grasha, A. F., Kirschenbaum, D. S. (1980). Psychology of Adjustment and Competence: Social isolation and loneliness. Cambridge: Winthrop Publishers

Gugus Tugas Percepatan Penanganan Covid-19. (2020, September, 8). Peta Sebaran Covid-19. Diakses dari https:// covid19.go.id/peta-sebaran.

Hazan, C. \& Shaver, P. R. (1994). Attachment as an organizational framework for 
research on close relationships. Psychological Inquiry, 5, 1-22.

Hirschberger, G., Florian, V., \& Mikulincer, M. (2003). Strivings for romantic intimacy following partner complaints or partner criticism: A terror management perspective. Journal of Social and Personal Relationships, 20, 675-687.

Karney, B.R., \& Bradbury, T.N. (1995). The longitudinal course of marital quality and stability: A review of theory, method, and research. Psychological Bulletin, 118, 3-34.

Kementerian Kesehatan. (2020, Juni, 19). Menuju Adaptasi Kebiasaan Baru. Diakses dari http://promkes.kemkes.go.id/menujuadaptasi-kebiasaan-baru.

Keputusan Menteri Kesehatan Nomor HK.01.07/Menkes/328/2020 tentang Panduan Pencegahan dan Pengendalian Corona Virus Disease 2019 (Covid-19) di Tempat Kerja Perkantoran dan Industri dalam Mendukung Keberlangsungan Usaha pada Situasi Pandemi.

Keputusan Presiden Nomor 11 Tahun 2020 tentang Penetapan Kedaruratan Kesehatan Masyarakat terkait Covid-19.

Keputusan Presiden Nomor 12 Tahun 2020 tentang Penetapan Bencana Nonalam Penyebaran Corona Virus Disease 2019 (Covid-19) Sebagai Bencana Nasional.

Lipman-Blumen, J. (1975). A crisis framework applied to macrosociological family changes: Marriage, divorce, and occupational trends associated with World War II. Journal of Marriage and the Family, 37, 889-902.

Mikulincer, M., Florian, V., \& Hirschberger, G. (2003). The existential function of close relationships: Introducing death into the science of love. Personality and Social Psychology Review, 7, 20-40.

Mikulincer, M., \& Florian, V. (2000). Exploring individual differences in reactions to mortality salience: Does attachment style regulate terror management mechanisms? Journal of Personality and Social Psychology, 79, 260-273.

Mukaromah, V. F. (2020, September, 1). Melihat Peningkatan Kasus Covid-19 di
Indonesia Dari Bulan Ke Bulan. kompas. com. Diakses dari https://www.kompas. com/tren/read/2020/09/01/200200165/ melihat-peningkatan-kasus-covid-19-diindonesia-dari-bulan-ke-bulan?page=all.

Nugraheny, D. E. (2020, April, 14). PSBB Di Indonesia 10 Daerah Disetujui 5 Ditangguhkan 2 Daerah Akan Ajukan. kompas.com. Diakses dari https://nasional. kompas.com/read/2020/04/14/06173261/ psbb-di-indonesia-10-daerah-disetujui5 -ditangguhkan-2-daerah-akanajukan?page=all.

Pekerja Dirumahkan dan Kena PHK Akibat Corona Capai 305 Juta. cnnindonesia.com. Diakses dari https://www.cnnindonesia.com/ ekonomi/20200720114203-92-526610/ pekerja-dirumahkan-dan-kena-phk-akibatcorona-capai-305-juta.

Peraturan Menteri Kesehatan (Permenkes) Nomor 9 Tahun 2020 tentang Pedoman Pembatasan Sosial Berskala Besar (PSBB).

Peraturan Pemerintah Nomor 21 Tahun 2020 tentang Pembatasan Sosial Berskala Besar (PSBB) dalam Rangka Percepatan Penanganan Covid-19.

PDSKJI. (2020, Mei, 14). Masalah Psikologis di Era Covid-19. Diakses dari http://pdskji. org/home.

Pusat Penelitian dan Pengembangan KB dan KS Badan Kependudukan dan Keluarga Berencana Nasional \& Institut Pertanian Bogor. (2020). Survei Kondisi Keluarga Pada Masa Pandemi Covid-19. Jakarta: BKKBN.

Robinson, D. L. (1997). Family stress theory: Implications for family health. Journal of the American academy of Nurse Practitioners, 9(1), 17-24.

Rosenblatt, P. C., Anderson, R. M., Johnson, P. A. (2010, Juni, 30). The Meaning of "Cabin Fever". Diakses dari http://www. tandfonline.com/loi/vsoc20 University of Minnesota.

Sarafino, E.P. (1994). Health Psychology (2.Ed). New York: Willey.

Sekretariat Kabinet Republik Indonesia. (2020, April, 23). Total 2 Provinsi dan 21 
Kabupaten Kota Termasuk Surabaya Kab Sidoarjo Serta Kab Gresik Terapkan PSBB. Diakses dari https://setkab.go.id/total2-provinsi-dan-21-kab-kota-termasuksurabaya-kab-sidoarjo-serta-kab-gresikterapkan-psbb.

South, S. J. (1985). Economic conditions and the divorce rate: A time-series analysis of the postwar United States. Journal of Marriage and the Family, 47, 31-41.

Sunarti, E. (2020). Laporan Survei Ketahanan Keluarga. [PowerPoint Slides].

Surat Edaran Nomor HK.02.01/ Menkes/335/2020 tentang Protokol Pencegahan Penularan Corona Virus Disease (Covid-19) di Tempat Kerja Sektor Jasa dan Perdagangan (Area Publik) dalam Mendukung Keberlangsungan Usaha.

Thakur, V. \& Jain, A. (2020). COVID 2019-suicides: A global psychological pandemic. Brain, behavior, and immunity, 88, 952-953. https://doi.org/10.1016/j. bbi.2020.04.062

Yeung, W.J., \& Hofferth, S.L. (1998). Family adaptations to income and job loss in the US. Journal of Family and Economic Issues, 19, 255-283.

Yossihara, A. (2020, September, 11). Covid-19 Makin Tak Terkendali. Kompas, hlm.15. 